\title{
夜間における都市公共空間の景観印象評価に関する研究 THE EVALUATION OF THE TOWNSCAPES IN THE PUBLIC SPACES AT NIGHT
}

\author{
吉沢望*, 石 原従 道**, 平手 小太郎*** \\ Nozomu YOSHIZAWA, Tsugumichi ISHIHARA and Kotaroh HIRATE
}

This paper focused on the townscapes in the public spaces at night and aimed at elucidating the evaluation structure and the relations between the evaluation factors and the physical elements.

Analyzed by SD method and factor analysis, 3 independent axes of "orderliness", "familiarity" and "uniqueness" were derived.

The factor of "orderliness" was related to the basic structure of the towns at night, and the "familiarity" and "uniqueness" were related to the attractiveness of the townscapes. All factors were highly estimated when the disposition of lighting was in order, while other physical elements influenced each factor in different ways.

\section{keywords : Townscapes, Lighting, Orderliness, Familiarity, Uniqueness, Caption Evaluation method} 都市景観、照明、秩序、親近性、個性、キャプション評価法

1、はじめに

1.1 研究の目的

夜間における都市景観においては人工照明が重要な役割を果たし ており、景観構成要素の主体となっている場合が多い。歴史的に見 れば、1960〜 70 年代の経済成長期には都市を明るくすることが先進 性の象徵であるかのように考えられ、全国的にどこでも同じような 道路照明、駅前広場照明、商店街照明が出現した。1980 年代には、 「ゆとり」・「アメニティ」の大切さがクローズアップされるようにな り、それ以後ライトアップに代表される演出照明が様々な場所で行 われるようになってきている。

ただし現在、日本の都市空間の照明は、建築物、街路あるいは広 場単位で個々の照明計画が行われていても、地域全体としての統一 的な計画が充分に施されないことが多い。これは照明計画自体、い わゆる照度、輝度で表される明るさのコントロールに主眼が置かれ ており、その地域の景観構成要素との関倸が充分に考えられていな いことの現れと考えられる。一方 1990 年代以降、市民参加による景 観形成がクローズアップされてきており、今後の景観形成には市民 の意見を無視することはできないであろう。このような状況を考え ると、今後の夜間における都市空間の景観形成は、人間の評価を基 に計画されるべきだと思われる。
しかし、夜間都市景観の照明分野全般に特化した人間の評価構造 の研究はまだ充分に為されていない。よって本研究では、多くの人 が集まり、利用し、知られている都市の代表的空間として、繁華街・ オフィス街・ショッピング街など（以下公共空間と呼ぶ）の照明に まず着目し、何が (要素)、どのようだから (特徵)、どのように評 価するのか (印象)、といった景観構成要素一人間間の評価構造つま り景観構成要素と評価尺度との関係を明確化することにより、夜間 の都市景観形成のための基礎的な視座を与えることを目的とする。

\section{2 既往研究の概要}

都市景観に関する研究は夜間に限定しなければ様々な事例 1)2)を 挙げることが可能であるが、その中で槙ら 3) は街路景観の好ましさ が「まとまり・落ち着き」「面白み・明るさ」の 2 尺度で説明され、 また街路景観の種類によらず一定であることを示している。本研究 においては夜間景観のうち特に繁華街などの都市公共空間に着目し ているが、この知見は非常に重要になる。また夜間景観を扱った研 究としては、望月ら 4) のライトアップの評価要因と評価との関係を 扱ったもの、また山本 5) 6) の特に街路灯に関わる操作要因と印象評 価との関係を導き出したものがあり、評価尺度の選定に当たっての 参考とした。本研究ではこれら既往研究を踏まえた上で、初めに夜
*イメージ情報科学研究所 研究員 · 博士 (工学)

** 横浜市企画局 技術吏員 · 修士 (工学)

**** 東京大学大学院工学系研究科建築学専攻 助教授・工博
Researcher, Laboratories of Image Information Science and Technology, Dr. Eng. Official, Planning Bureau, City of Yokohama, M. Eng.

Assoc. Prof., Dept. of Architecture, Grad. Sch. of Engineering, the Univ. of Tokyo, Dr. Eng. 
間に限定した都市公共空間全般の評価構造を導き出し、次に照明を 中心としながら建物・空間その他の要因をも考虑に入れ、夜間にお ける都市公共空間の印象評価と景観構成要素との関係を明らかにし ていく。

\section{2、都市公共空間における現場印象評価実験}

2.1 実験方法

\subsection{1 評価対象の選定}

都市公共空間の代表的空間として東京の啮谷地区と新宿地区を選 んだ。渋谷地区は繁華街、新宿地区は主としてオフィス（高層ビル） 街である。初めに 2.1.2 の実験の評価対象を選定するため、白地図に よる認知マップ手法を用いた予備的な面接調查注 1)を行った。被験 者には、光・照明の要素とその特徵に関して、思い出すもの全てを 白地図上に書き込みさせ、さらに好きな場所・嫌いな場所に印をつ け、その理由を記入させた。この手法を採った理由としては、1）実 験者による評価対象の恣意的な選定を避ける、2）想起させること により印象の強いものを優先的に選ばせる、ことによる。被験者は 首都圈在住の一般大学生 10 名である。

その結果、渋谷地区では JR 渋谷駅前から放射状に延びる大通りと その周辺の建物が、新宿地区では類似した建物が集まる街区が $50 \%$ 以上の被験者に共通した強く想起される都市空間であった。これら 言及頻度の高かった場所を中心に、評価対象として渋谷地区 12 箇所・ 新宿地区 10 筒所、合計 22 箇所を選定した。
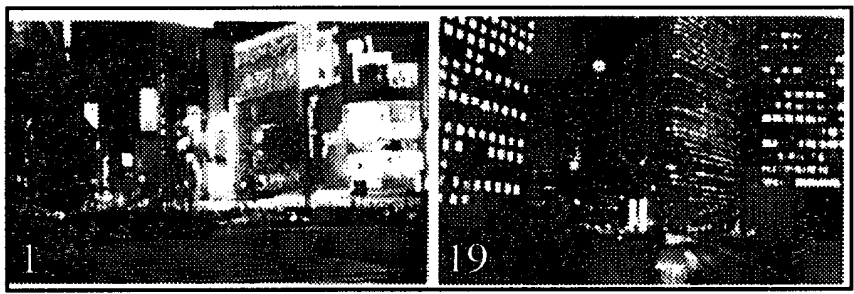

図 1. 評価対象例（左下数字は場所番号）

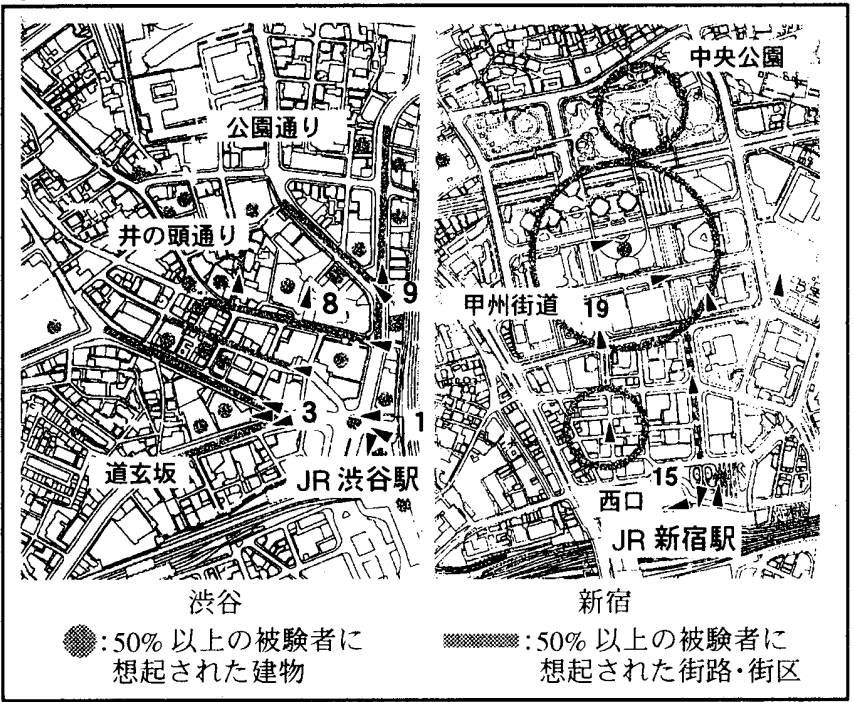

図 2.2 地区における視点場と視線方向（数字は場所番号）

図 2 に両地区において言及頻度の高かった街路・街区と、評価対 象として選定した視点場と視線方向を示す。矢印の根元が視点場、矢 印の方向が視線方向を表す。

\section{1 .2 実験の概要}

面接調査において好き嫌いの理由として挙げられた言葉の中か ら、既往研究 4)5)6) を参考にして、7 段階 SD 法用の 17 個の評価尺 度湆：2）を選定した。同時に「良い一悪い」による総合評価としての 〈判断〉尺度を用意した ${ }^{3}{ }^{3)}$ 。被験者には、18：00〜20：00 の時間帯 に2.1.1で選定した 22 籄所それぞれの実際の視点場で、視線方向を

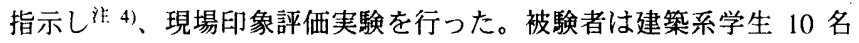
である。

\section{2 実験結果}

\subsection{1 因子分析の結果}

SD 法用の 17 尺度の評定平均值（17 尺度 $\times 22$ 简所）を因子分析 （主因子法、バリマックス回転）したところ、第 3 因子までの寄与率 が高くかつ累積寄与率が $87 \%$ を越えたので、表 1 に示す 3 因子で説 明することにした。

第 1 因子は「落ち着いた・整然とした」等で、『秩序』因子とする。 第 2 因子は「親しみのある・暖かい」等で、『親近性』因子とする。 第 3 因子は「個性的な・新しい」等で『個性』因子とする。それぞ れの因子と〈判断〉尺度との相関をみると、表 2 に示すように『親 近性』・『個性』との相関が大きい。

表 1. 因子分析の結果

\begin{tabular}{|l|r|r|r|}
\hline \multicolumn{1}{|c|}{ 尺度 } & $\begin{array}{c}\text { 第一因子 } \\
\text { 『秩序』 }\end{array}$ & \multicolumn{1}{c|}{$\begin{array}{c}\text { 第二因子 } \\
\text { 『親近性』 }\end{array}$} & $\begin{array}{c}\text { 第三因子 } \\
\text { 『個性』 }\end{array}$ \\
\hline 落ち着いた & 0.96 & 0.13 & -0.07 \\
\hline 整然とした & 0.94 & -0.20 & -0.02 \\
\hline まとまりのある & 0.92 & 0.02 & 0.03 \\
\hline 活気のある & -0.93 & 0.16 & 0.17 \\
\hline 派手な & -0.83 & -0.05 & 0.51 \\
\hline 明るい & -0.73 & -0.06 & 0.36 \\
\hline やわらかい & -0.04 & 0.97 & 0.07 \\
\hline 親しみのある & 0.01 & 0.92 & 0.32 \\
\hline 自然な & 0.35 & 0.86 & -0.20 \\
\hline 暖かい & -0.30 & 0.85 & 0.23 \\
\hline 都会的な & -0.15 & -0.68 & 0.64 \\
\hline 新しい & 0.17 & -0.29 & 0.89 \\
\hline 個性的な & -0.15 & 0.40 & 0.80 \\
\hline 変化のある & -0.47 & 0.24 & 0.78 \\
\hline 開放的な & -0.13 & 0.00 & 0.78 \\
\hline 面白い & -0.29 & 0.45 & 0.76 \\
\hline 美しい & 0.69 & 0.34 & 0.59 \\
\hline \hline 奇与率 & $\mathbf{4 0 . 3}$ & $\mathbf{2 7 . 1}$ & $\mathbf{1 9 . 9}$ \\
\hline 累積奇与率 & $\mathbf{4 0 . 3}$ & $\mathbf{6 7 . 4}$ & $\mathbf{8 7 . 3}$ \\
\hline
\end{tabular}

表 2. 各因子と〈判断〉尺度との相関

\begin{tabular}{|r|r|r|r||r|}
\hline & 秩序 & 親近性 & 個性 & 決定係数 \\
\hline 〈判断〉尺度との相関 & 0.41 & 0.67 & 0.56 & 0.93 \\
\hline
\end{tabular}

2.2.2 評価対象のグループ分け

各評価対象の因子得点を用いてクラスター分析（ウォード法）を 行った結果から、評価対象を 6 グループに分類した。3因子によって 張られる因子空間上に対象を布置すると図 3 のようになる。 
グループの分類を見やすくするため、視点と軸の関係について調整 を行った。各グループの特徴を表 3 に示す。

\subsection{3 各因子と評価対象の特徴の関俰}

図 3 及び表 3 から各因子と評価対象のグループの特徵との関係を 解釈すると、第 1 因子『秩序』は、照明色の統一性、分布の規則性、 建物・街路の形態的単純さが、第 2 因子『親近性』は、暖色系照明 使用、人・樹木の存在が、第 3 因子『個性』は、駅前や大きな広場 など開放感の高い空間が、それぞれ関わりを持つことが明らかに なった。

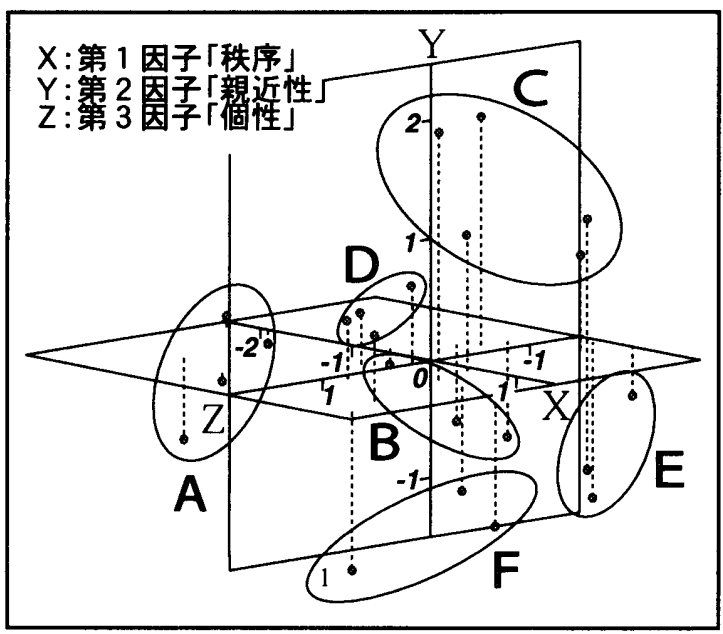

図 3. 評価対象の因子空間上の布置

表 3. 評価対象のグループ

\begin{tabular}{|c|c|c|c|c|c|}
\hline ク & \multirow[t]{2}{*}{ 街区 } & \multirow[t]{2}{*}{ 照明の要素 } & \multicolumn{3}{|c|}{ 特徽 } \\
\hline $\begin{array}{l}2 \\
1\end{array}$ & & & 照明色 & $\begin{array}{l}\text { 建築物 } \\
\text { の外観 }\end{array}$ & 人 \\
\hline A & 繁華街 & 看板・ネオン & $\begin{array}{l}\text { 非常に } \\
\text { 多様 }\end{array}$ & $\begin{array}{l}\text { 非常に } \\
\text { 不規則 }\end{array}$ & 多い \\
\hline B & 繁華街 & 看板・ネオン & 多様 & 不規則 & 多い \\
\hline $\mathrm{C}$ & ショッピング街 & $\begin{array}{l}\text { 街灯 } \\
\text { 店内部の光 }\end{array}$ & 暖色 & 不規則 & 多い \\
\hline D & ショッピング街 & 店内部の光 & $\begin{array}{l}\text { 暖色 + } \\
\text { 白色 }\end{array}$ & 規則的 & 多い \\
\hline$E$ & 不特定 & 街灯 & 白色 & 規則的 & 多い \\
\hline $\mathrm{F}$ & オフィス街 & $\begin{array}{l}\text { 街灯 } \\
\text { 窓 }\end{array}$ & 白色 & 規則的 & 少ない \\
\hline
\end{tabular}

\section{3、印象評価と景観構成要素との関係の検討－面接調查}

次に印象評価と景観構成要素との関係をさらに明らかにするため に、キャプション評価法 7) 注 5) を参考にし、面接調查を行った。被 験者は2.1.1 に示した被験者 10 名中の 9 名である。現場印象評価実 験 (2.)の視点場で撮影した写真注 6) 22 枚を見せ、「○○〈要素〉が $\triangle$ $\triangle\langle$ 特徵〉だから口ロ〈印象〉であり、良い／悪い〈判断〉と思う」 という形で答えさせる方法を用いた。

\section{1 単純集計結果}

面接調査の結果、〈要素〉に関する言葉は計 181 個抽出され、それ らをさらに照明、人、道路、建物、車などの項目に練分類した。照 明に関する項目は 82 個で、最も多く全体の 4 割を占めており、夜間
景観における照明の重要性が示されたものと考えられる。〈印象〉に 関する言葉を 2.2.1 の因子分析の結果に基づいて分類すると、第 1 因 子『秩序』と第 3 因子『個性』に関する言葉がそれぞれ 87 個、 77 個 と多く、第 2 因子『親近性』に関する言葉は 22 個と少ない。しかし 因子分析の結果からは、第 2 因子と〈判断〉尺度との相関 $(0.67)$ が 高くなっており、因子として無視できないと判断した。

$3.2\langle$ 要素〉、〈特徵〉、〈印象〉の関係

〈要素〉、〈特徵〉、〈印象〉の中で、 2 人以上が関係づけた項目（太 線は 4 人以上）を構造化し樹形図にすると、図 4 のようになる。(仰 象〉の項目に付けた数字は対応する因子を表す。O囲みは SD 法用の 評価尺度として使用しているもの、四囲みはその因子と相関の高い 評価尺度と意味が近いと判断したものを表す。）

この結果から、照明、看板・ネオン、人、樹木など個別の要素に 関すること（図 4 の上部）は第 1 因子『秩序』あるいは第 2 因子『親 近性』と関係が強い〈印象〉の言葉を用いているといえる。一方、建 物や空間、広場など空間構成に関連のある対象（図 4 の下部）の印 象は、第 3 因子『個性』之関係の強い〈印象〉の言葉を用いている。 よって 2.2.3 の結果とあわせて、照明を改善することで、第 1 因子 『秩序』、第 2 因子『親近性』に関しての印象の向上の可能性が高い ことがわかった。

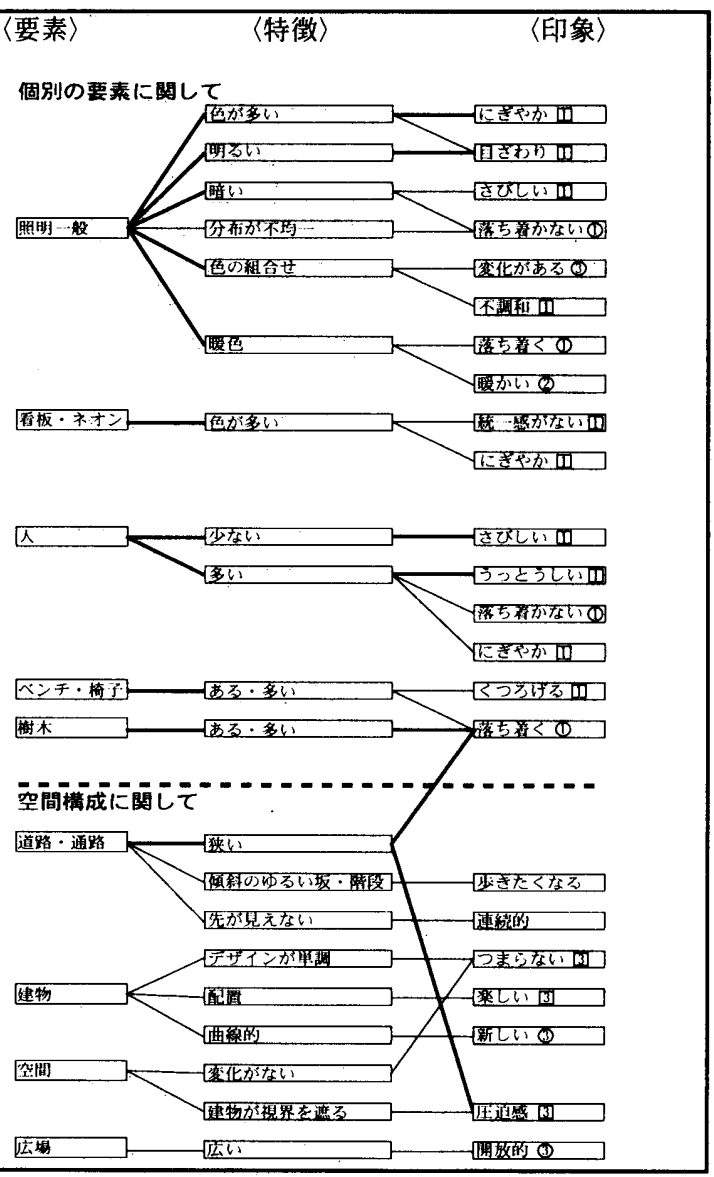

図 4.〈要素〉・〈特徴〉・〈印象〉の関係 


\section{4、照明の変化が印象評価に与える影響の検証ースライド実験 4.1 実験概要}

照明改善が印象評価に影響を与えることを検証するために、現場 印象評価実験 (2.) の視点場で撮影した写真に画像処理を施したスラ イドを対象にし、SD法を用いた被験者評価実験（以下スライド実験 と称す）を行った。画像処理を施す〈要素〉としては、人工照明に 関するもの、夜間景観において重要なもの（=面接調査（3.)におけ る言及頻度の高いもの)、設計対象となるもの、以上 3 条件を満たす ものとして、「照明一般」と「看板・ネオン」を選択した。実験対象 は2.2.2におけるA〜 F の対象のグループ分け（表 3 ）をもとに、そ れぞれのグループから 1 籄所ずつ選んだ。SD 法の評価尺度は 2.2.1の 結果で因子負荷量の高いものと、面接調査（3.) で〈印象〉に対して 挙げられた言葉から総合的に判断して、表 5 に示す 7 尺度を選定し、 2.1.2 と同じょうに〈判断〉尺度「良い一悪い」を加えた。被験者は 建築系の学生 10 名である。

4.1.1 実験対象 : 画像処理に関して

繁華街であるグループ A・B から選んだ対象に関しては、「色が多 い、明るい、分布が不均一」等の〈特徵〉があり、「悪い」という 〈判断〉結果が得られたことから、「看板・ネオンを消す」処理を、そ れぞれ「半減」「全て消す」の 2 段階で施した。これは画像処理ソフ トにより看板・ネオン部分の輝度及び彩度（飽和度）を下げ、背景 の暗い部分と同化させる処理を行っている。なお「半隇」について は、写真上の看板・ネオンの中から分布が均等になるように消去す るもの半数を選び上記の処理を施した。

グループ C・D は照明色は「暖色系」であるといった〈特徵〉を もっている。また全体的には「良い」という〈判断〉結果が得られ ているので、グループC・Dから選んだ対象に関しては現状のままで 変化させる必要はないと判断し、画像処理は施していない。

グループ $\mathrm{E} \cdot \mathrm{F}$ から選んだ対象に関しては、画像処理ソフトにより 照明色を変化させ、街灯と建物内部の照明について「暖色系」「白色 系」の組み合わせすべてを揃えたスライドを作成した。

以上、計 16 個の実験対象を表 4 に示す。

表 4. 実験対象一覧

(○は現状のまま、○は〈要素〉を変化させた対象）

\begin{tabular}{|c|c|c|c|c|c|}
\hline \multirow[b]{2}{*}{ グループ } & \multirow{2}{*}{$\begin{array}{l}\text { 場所 } \\
\text { 番号 }\end{array}$} & \multicolumn{3}{|c|}{ 看板・ネオン } & \\
\hline & & 現状 & 半減 & 全て消す & \\
\hline A & 1 & - & 0 & 0 & \\
\hline$B$ & 3 & 은 & 0 & 0 & \\
\hline グループ & $\begin{array}{l}\text { 場所 } \\
\text { 番号 }\end{array}$ & 現状 & & & \\
\hline$C$ & 9 & - & & & \\
\hline$D$ & 15 & 운 & & & \\
\hline \multirow[b]{2}{*}{ グループ } & \multirow{2}{*}{$\begin{array}{l}\text { 場所 } \\
\text { 番 }\end{array}$} & \multicolumn{4}{|c|}{ 色 (街灯 - 建物内部) } \\
\hline & & 白色・主你 & 暖色・过色 & 白危・䁔色 & 暖色・暖绝 \\
\hline$E$ & 8 & 0 & 0 & 0 & 0 \\
\hline$F$ & 19 & - & 0 & 0 & 0 \\
\hline
\end{tabular}

\section{1 .2 実験方法}

スクリーンと被験者との間隔は、画角が撮影された写真と一致す るように調整し、また照明状態に関しては、実験室（暗室）内部の
照明はすべて消灯し、スライドプロジェクターの光のみの状態で実 験を行った。なお実験開始にあたり照明を落とした状態で約 10 分間 実験手順に関する説明を行うことにより、被験者を暗さに順応させ ている。

4.2 スライド実験の分析のための評価尺度の検証

スライド実験の分析にあたって、現場の再現性という観点から有 効と見なせる評価尺度を選定するために、現状のままのスライド (表 4 のの印）に対する印象評価の結果を、同じ視点場の現場印象評価 実験（2.）における評価と比較した。提示手法（スライド・現場）。 実験対象を要因とした 2 元配置分散分析の結果を表 5 に示す。

「整然とした」、「明るい」、「暖かい」の 3 尺度について、提示手法 あるいは提示手法と評価対象の交互作用に有意差が見られた。よっ て以降の分析においては以上の 3 尺度は除外し、提示手法間の有意 差が見られなかったもののうち「落ち着いた」、「親しみのある」、個 性的な」を各因子『秩序』『親近性』『個性』の代表尺度として、〈判 断〉尺度と共に以下の分析に用いた。

表 5. 分散分析表

\begin{tabular}{|c|c|c|c|c|}
\hline & 尺度 & 提示手法 & 実験対象 & $\begin{array}{c}\text { 提示手法 } \times \\
\text { 実験対象 }\end{array}$ \\
\hline \multirow{3}{*}{$\begin{array}{c}\text { 第 } 1 \text { 因子 } \\
\text { 『秩序』 }\end{array}$} & 落ち着いた & & ** & \\
\hline & 整然とした & ** & ** & ** \\
\hline & 明るい & ** & ** & * \\
\hline \multirow{2}{*}{$\begin{array}{l}\text { 第 } 2 \text { 因子 } \\
\text { 『親近性』 }\end{array}$} & 親しみのある & & ** & \\
\hline & 暖かい & $*$ & ** & ** \\
\hline \multirow{2}{*}{$\begin{array}{c}\text { 第 } 3 \text { 因子 } \\
\text { 『個性』 }\end{array}$} & 個性的な & & ${ }^{* *}$ & \\
\hline & 変化のある & & ** & \\
\hline 〈判断〉 & 良い & & $* *$ & \\
\hline
\end{tabular}

4.3 看板・ネオンを消すことによる効果

看板・ネオンを減らすことの効果を調べるため、看板・ネオン、場 所を要因とした 2 元配置の分散分析を行った。結果を表 6 に示す。

表 6. 分散分析表 (看板・ネオン)

\begin{tabular}{|c|c|c|c|c|}
\hline & 尺度 & 看板・ネオン & 堵所 & 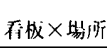 \\
\hline 秩序』 & 洛ち着いた & $*$ & & \\
\hline 『新近性』 & 親しみのある & & & \\
\hline 『個性』 & 做性的な & * & & \\
\hline 〈判断〉 & 郎い & & & \\
\hline
\end{tabular}

この結果、看板・ネオンの主効果について有意差の見られた評価 尺度は、「落ち着いた」(『秩序』因子) と「個性的な」(『個性』因子) であった。また、それらの尺度について評定平均値をグラフにした ものを図 5 に示す。なお凡例の A 1 は A グループの場所 1、B3 は B グループの場所 3 を示す。

「看板・ネオンを消す」が、「落ち着いた」に関しては落ち着いた 印象を上げる方向に、また「個性的な」に関しては個性的ではない 印象を与える方向に作用していることが示された。 


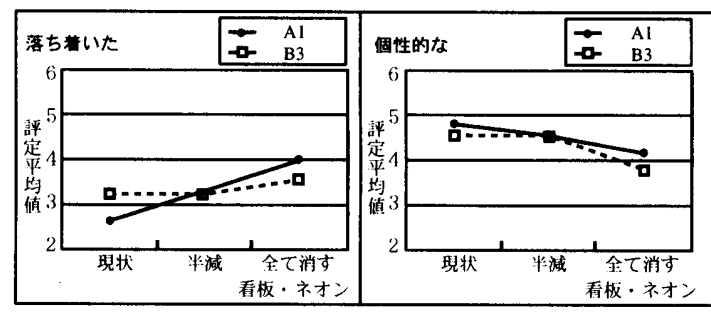

図 5. 実験対象（看板・ネオンの量を変化）と評定平均値との関係

4.4 街灯・建物内部の照明色の効果

照明色の効果を調べるため、街灯の照明色、建物内部の照明色、場 所を要因とした 3 元配置分散分析を行った。分散分析表の一部を表 7 に示す。

表 7. 分散分析表（照明色）

\begin{tabular}{|c|c|c|c|c|c|c|c|c|}
\hline & & & & & & & & 街 \\
\hline & 及度 & $\begin{array}{l}\text { 街 } \\
\text { 灯 }\end{array}$ & $\begin{array}{l}\text { 建 } \\
\text { 物 }\end{array}$ & $\begin{array}{l}\text { 昜 } \\
\text { 所 }\end{array}$ & $\begin{array}{c}\text { 灯 } \\
\times \\
\text { 建 } \\
\text { 物 }\end{array}$ & 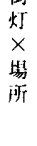 & $\begin{array}{l}\text { 物 } \\
\times \\
\text { 埸 }\end{array}$ & $\begin{array}{l}\times \\
\times \\
\text { 建 } \\
\text { 物 } \\
\times \\
\text { 繁 }\end{array}$ \\
\hline 『秩序』 & 落ち着いた & & ** & & & & ** & \\
\hline 『親近性』 & 親しみのある & & $* *$ & $* *$ & & & $*$ & \\
\hline 『個性』 & 倜性的な & & $* *$ & & & & & \\
\hline <判醉> & 艮い & & ** & $* *$ & & & $*$ & \\
\hline
\end{tabular}

街灯の照明色の違いによる影響および色の組み合わせによる影響 (街灯×建物)については明確な関係はみられない。よって建物内部

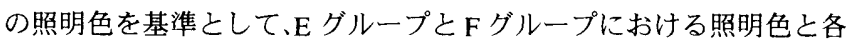
尺度の評定平均値との関係を表すグラフを図 6 に示す。なお $\mathrm{E} 8$ は $\mathrm{E}$ グループの場所 8、F19 はFグループの場所 19 を示す。

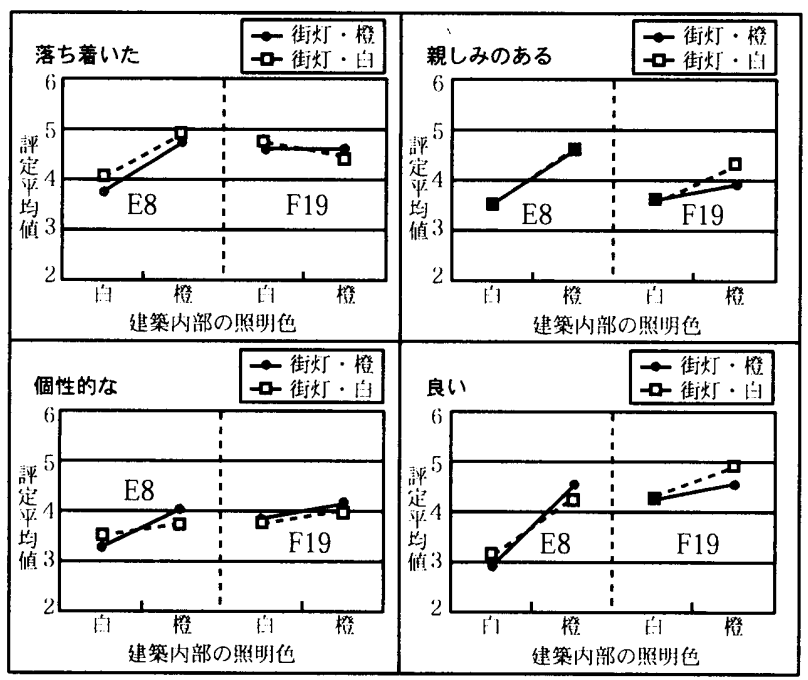

図 6. 実験対象（照明色を変化）と評定平均値との関係

上図より、建物内部の照明色が暖色系であることが、「親しみのあ る」（『親近性』因子）と〈判断〉尺度の評価を上げることが明らか になった。
4.5 照明の変化が与える影響についてのまとめ

『秩序』因子亡『親近性』因子の代表尺度「落ち着いた」「親しみ のある」を用いて、印象の変化をまとめると図 7 のようになる。(本 来 E8 は照明色を暖色＼cjkstart白色に変化させた実験対象であるが、ここで は表現を白色 $\rightarrow$ 暖色に統一して示してある。）

看板・ネオンを消すことで『秩序』因子を上げる効果が、建物内 部に暖色の照明を用いることで『親近性』因子を上げる効果がそれ ぞれみられた。

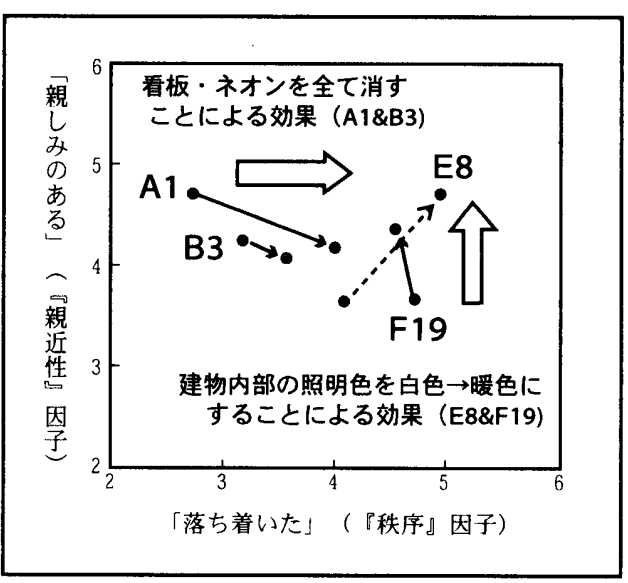

図 7. 照明の変化による印象の変動

\section{5、一般化のための検証－現場踏查実験}

これまでの一連の実験・調查はすべて新宿・渋谷という限られた 地区が対象であった。これらから明らかになった評価構造が一般的 な公共空間で適用できるかどうか、また〈印象〉を左右する〈要素〉 の〈特徵〉に関してデータの補完をするため、評価対象を被験者自 身に選択させ、場所に関する様々な評定をその場で行わせる現場踏 査実験を実施した。

\section{1 実験方法}

面接調査（3.）で抽出された景観構成要素をもとに表 8 に示す調査 項目涪 7)を作成した。

\begin{tabular}{|c|c|}
\hline 項目 & カテコリー \\
\hline 榰所以分 & 街路・运場 \\
\hline 街区分 & 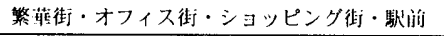 \\
\hline 然明種類 & 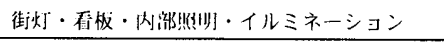 \\
\hline 暃明分布 & 规㺫阶一不覞剘 \\
\hline 明るさ & 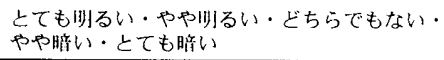 \\
\hline 照明色 & 多い・どちらでもない，少ない \\
\hline 企体的な任 & 暧色系・们他系・汹少 \\
\hline 建物の高さ & ॠ地_階建厂 \\
\hline 道路の広さ & 里＿台分 \\
\hline 步道の広さ & $-m$ \\
\hline 道路の形状 & まっすぐー曲がっている \\
\hline 道路の偭斜 & あるーない \\
\hline 尖道の哺裴 & されているーされていない \\
\hline 樹术 & あるーない \\
\hline 人 & 多いー少ない \\
\hline
\end{tabular}


被験者は「多くの人が集まり、利用し、知られている場所を選択 して下さい」という教示により自分自身で自由に視点場を選択し、現 地に直接行って、評価対象空間の写真を撮影し声 8)、2.1.2 で示した SD 法用の 17 尺度および〈判断〉尺度で景観評価を行い、さらに表 8 の調査項目に回答した。被験者は建築系の学生 17 名で、選択され た対象は表 9 に示す計 201 箇所となった。

表 9. 被験者の選択した評価対象の地区別分類

\begin{tabular}{|c|c|c|c|c|c|}
\hline 池袋 & 39 & 中野 & 14 & 銀座 & 8 \\
\hline 水道橋 & 27 & 表参道 & 12 & 秋莱原 & 7 \\
\hline 政田橋 & 20 & 渋行 & 9 & 有楽町 & 6 \\
\hline 新缩 & 20 & 原缩 & 9 & その他 & 30 \\
\hline
\end{tabular}

5.2 因子分析

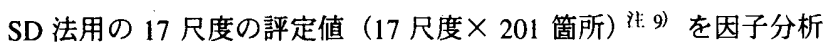
（主因子法、バリマックス回転）したところ、第 3 因子までの奇与率 が $65.9 \%$ 注 10) であった。従って以下における分析では表 10 に示す 3 因子で説明する。

表 10. 因子分析の結果

\begin{tabular}{|c|c|c|c|}
\hline 尺度 & $\begin{array}{c}\text { 第 } 1 \text { 因子 } \\
\text { 親近性』 }\end{array}$ & $\begin{array}{c}\text { 第 } 2 \text { 因子 } \\
\text { 『秩序』 }\end{array}$ & $\begin{array}{c}\text { 第 } 3 \text { 因子 } \\
\text { 蔨性」 }\end{array}$ \\
\hline やわらかい & 0.82 & 0.04 & 0.04 \\
\hline 暖かい & 0.81 & -0.27 & 0.16 \\
\hline 親しみのある & 0.80 & 0.06 & 0.19 \\
\hline 自然な & 0.74 & 0.22 & .0 .10 \\
\hline 面白い & 0.61 & -0.41 & 0.39 \\
\hline 開放的な & 0.46 & -0.15 & 0.25 \\
\hline 落ち着いた & 0.23 & 0.80 & 0.26 \\
\hline 整然とした & 0.21 & 0.78 & 0.37 \\
\hline 活気のある & 0.13 & -0.78 & 0.10 \\
\hline 派手な & 0.05 & -0.77 & 0.39 \\
\hline まとまりのある & 0.29 & 0.63 & 0.56 \\
\hline 明るい & 0.15 & -0.63 & 0.41 \\
\hline 変化のある & 0.35 & -0.63 & 0.21 \\
\hline 新しい & 0.26 & -0.18 & 0.77 \\
\hline 都会的な & -0.13 & .0 .13 & 0.76 \\
\hline 個性的な & 0.24 & 0.07 & 0.69 \\
\hline 美しい & 0.59 & 0.29 & 0.59 \\
\hline 寄与率 & 31.14 & 24.01 & 10.78 \\
\hline 累積奇与率 & 31.14 & 55.15 & 65.93 \\
\hline
\end{tabular}

第 1 因子は「やわらかい」「親しみのある」等で『親近性』因子とす る。第 2 因子は「落ち着いた」「整然とした」等で、『秩序』因子と する。第 3 因子は「新しい」「個性的な」等で、『個性』因子とする。 それぞれの因子と〈判断〉尺度との相関を見ると、表 11 に示すよう に『親近性』、『個性』との相関が大きい。

表 11. 各因子と〈判断〉尺度との相関係数

\begin{tabular}{|c|r|r|r||r|}
\hline & 親近性 & \multicolumn{1}{|c|}{ 秩序 } & \multicolumn{1}{c|}{ 個性 } & 決定係数 \\
\hline 〈判断〉尺度との相関 & 0.65 & 0.11 & 0.49 & 0.68 \\
\hline
\end{tabular}

現場印象評価実験（2.）の結果（表 1 ）と比較すると、順序が翼な るとは言え、全体としては上位 3 因子は一致している壮11)と判断し
た。このことから夜間における都市公共空間の景観の評価構造がこ の 3 因子で説明可能であることを確認した。

\section{3 各因子と景観構成要素之の関倸}

夜間における都市公共空間の景観印象評価に関わる因子と景観構 成要素との関係を包括的かつ単純化して捉え、都市景観形成の際の 基礎的な視座を与えることを目的に以下の分析を行った。

各因子の因子得点と景観構成要素との関係を調べるために、それ ぞれの要因の主効果について一元配置分散分析を行つた結果を表 12 に示す。照明の分布と看板の数はすべての因子に関して有意差が見 られ、印象評価に影響を与えていることが分かった。

表 12. 分散分析表

\begin{tabular}{|c|c|c|c|c|}
\hline \multicolumn{2}{|c|}{ 景観構成要素 } & 親近性 & 秩序 & 個性 \\
\hline \multirow{6}{*}{$\begin{array}{l}\text { 照明 } \\
\text { 要因 }\end{array}$} & 照明の分布 & ** & ** & ** \\
\hline & 照明の色 & ** & $* \star$ & \\
\hline & 明るさ & & ** & \\
\hline & 看板の数 & 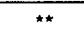 & $\overline{* \star}$ & ** \\
\hline & 街灯 & & & ** \\
\hline & イルミネーション & * & & * \\
\hline \multirow{5}{*}{$\begin{array}{l}\text { 空間 } \\
\text { 要因 }\end{array}$} & 建物の高さ & & $*$ & * \\
\hline & 道路の広さ & * & $* \star$ & \\
\hline & 歩道の広さ & ** & & \\
\hline & 道路の形状 & & & \\
\hline & 道路の傾斜 & & & \\
\hline \multirow[t]{3}{*}{ その他 } & 歩道の舗装 & * & * & \\
\hline & 樹木.ベンチ & * & & \\
\hline & 人 & & ** & \\
\hline
\end{tabular}

次に有意差の見られた景観構成要素に対して、各カテゴリーごと の因子得点平均值のグラフを図 8 に示す洋 12)。

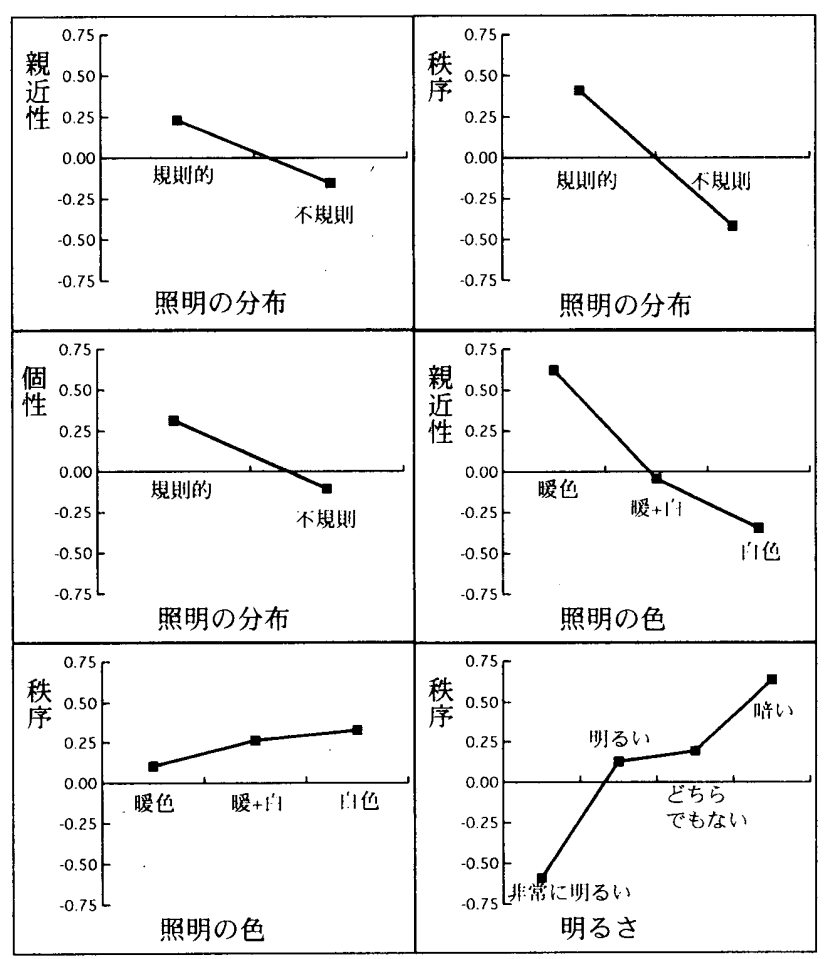




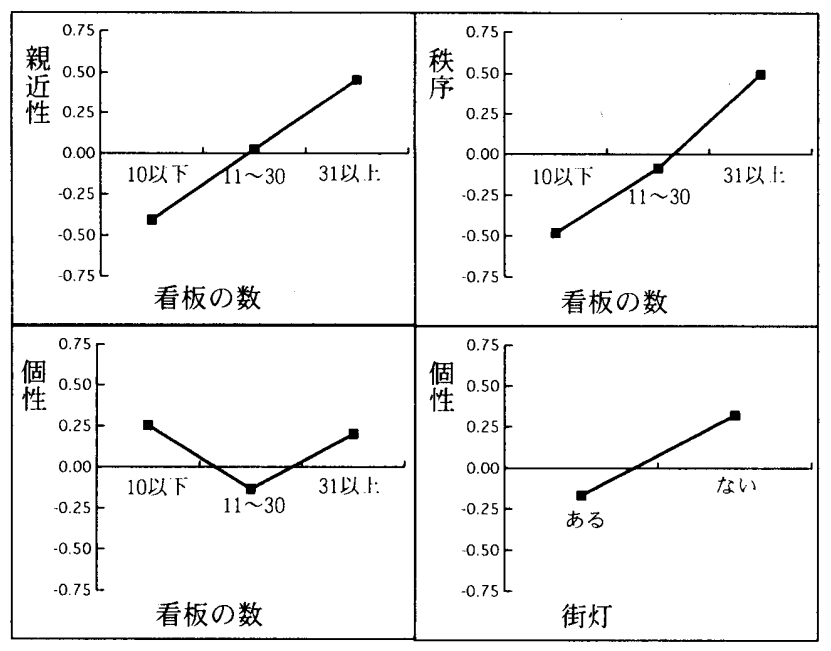

図 8. 景観構成要素・各カテゴリーごとの因子得点平均值（因子別）

以上より因子と景観構成要素の関係を表 13 のようにまとめた。

景観構成要素の「照明分布」が規則的であると、いずれの因子の 場合も因子得点が高くなる。「照明の色」に関しては、『秩序』因子 では白色の方が、『親近性』因子では暖色の方が因子得点が高くなり、 互いに相反する結果となっている。「看板の数」に関しては、少ない 場合はいずれの因子においても因子得点が高くなるが、反対に非常 に多くても『個性』因子のみは因子得点が高くなることが特徽的で ある。

表 10 の因子分析の結果と表 13 の因子と景観構成要素の関係から、 各因子の意味付けを包括的に解釈すると以下のようになる。『親近 性』因子に関しては、「暖かい」「自然な」などの尺度との相関が高 く、「暖色系の照明」「看板の数が少ないこと」「イルミネーションの 存在」が評価に対するプラス要因として働くことから、街の親しみ やすさに関わる因子と捉えられる。『秩序』因子に関しては、「落ち
表 13. 因子と景観構成要素との関係

\begin{tabular}{|c|c|c|c|c|c|c|}
\hline \multirow{2}{*}{$\frac{\text { 因 }}{\text { 子 }}$} & \multicolumn{3}{|c|}{ 照明要因 } & \multicolumn{3}{|c|}{ 空間要因 • その他 } \\
\hline & 要素 & + & - & 要素 & + & - \\
\hline \multirow{4}{*}{$\begin{array}{l}\text { 親 } \\
\text { 近 } \\
\text { 吽: }\end{array}$} & 照明分布 & 規則的 & 不䙺划 & 歩道の塗装 & ある & ない \\
\hline & 照明の色 & 暖任 & 当弁 & 樹木ベンチ & ある & ない \\
\hline & 㶾板の数 & 少ない & 多い & 道路の広さ & & 狄い \\
\hline & $\begin{array}{l}\text { イルミネー } \\
\text { ション }\end{array}$ & ある & ない & 歩道の広さ & & 狄・㕕 \\
\hline \multirow{4}{*}{$\begin{array}{l}\text { 秋 } \\
\text { 序 }\end{array}$} & 照明分布 & 规划的 & 不規則 & 歩道の塗装 & ある & ない \\
\hline & 照明の色 & 尚自 & 暖色 & 人 & 少ない & 多い \\
\hline & 要板の数 & 少ない & 多い & 建物の專さ & 低い & 尚W \\
\hline & 明るさ & 暗い & $\begin{array}{l}\text { 非染に } \\
\text { 时るい }\end{array}$ & 道路の広さ & & 迅证 \\
\hline \multirow{4}{*}{$\begin{array}{l}\text { 倈 } \\
\text { 怢: }\end{array}$} & 照明分布 & 䙺划的 & 不規划 & 建物の高さ & $n$ & 低い \\
\hline & 番板の数 & 少 or 多 & 算通 & & & \\
\hline & $\begin{array}{l}\text { イルミネー } \\
\text { ション }\end{array}$ & ある & ない & & & \\
\hline & 街灯 & ない & ある & & & \\
\hline
\end{tabular}

着いた」「整然とした」などの尺度との相関が高く、「白色系の照明」 「看板の数が少ないこと」「建物の低いこと」などがプラス要因とし て働くことから、街の基本的形態を表していると思われる。『個性』 因子については、「新しい」「個性的な」などとの尺度との相関が高 く、「看板が少ないこと」「看板が多いこと」「イルミネーションの存 在」「建物の高いこと」などがプラス要因に働くことから、街の個性 的な魅力を表していると考えられる。

\section{6、まとめ}

本研究における結論望 13) を図 9 及び以下のようにまとめた。

1 . 夜間における都市公共空間の景観を評価する因子は『秩序』親 近性』『個性』の3 因子に集約される（表 1、表 10）。

2.『秩序』因子は街の基本的形態と関係している。ただし良い悪 いという総合評価との関連性は低い（表11 の相関係数）。

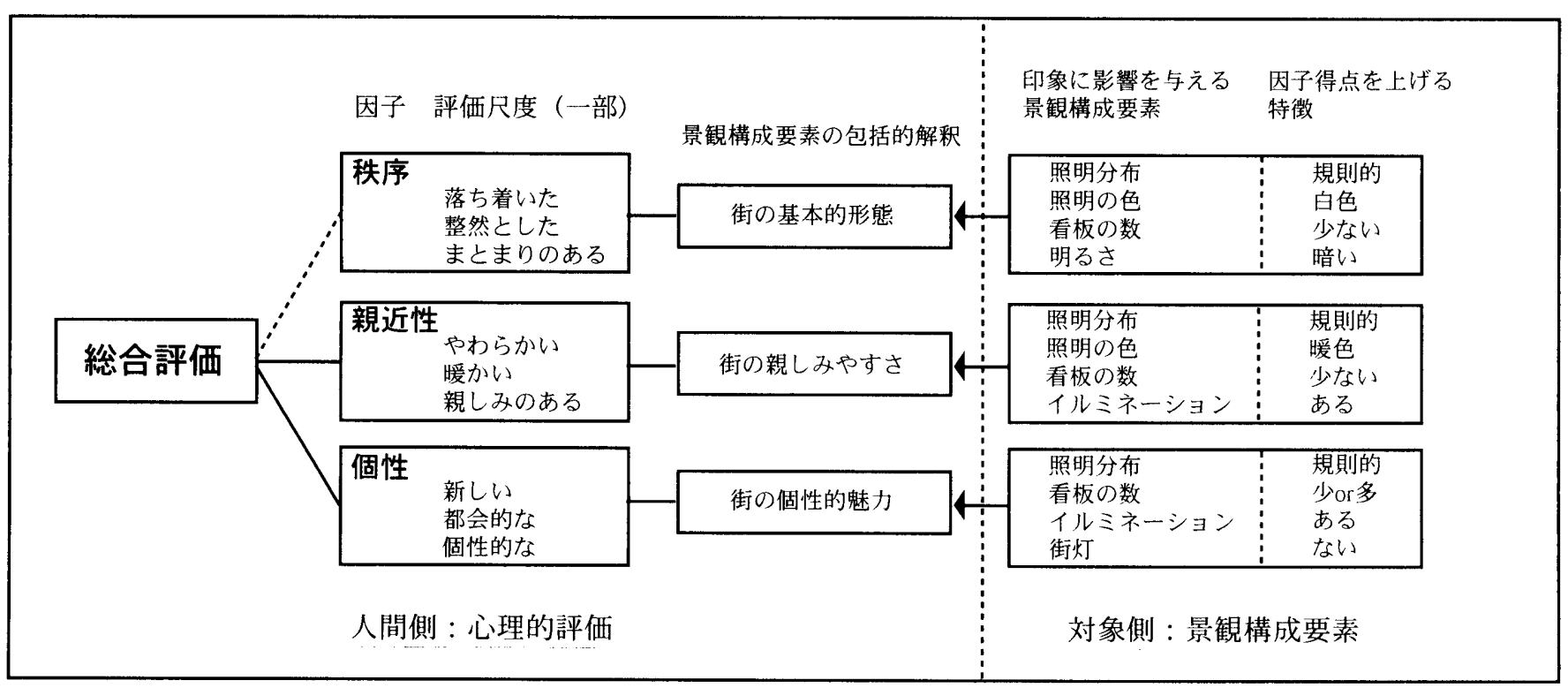

図 9 夜間における都市公共空間の景観の印象評価構造 
3、『親近性』及び『個性』因子は総合評価に与える影響が大きく （表 11）、『親近性』因子には街の親しみやすさが、『個性』因子には 街の個性的な魅力が関係していると考えられる。

以上から夜間における都市公共空間の夜間景観を形成する場合に は、街の基本的形態 (『秩序』)、街の親しみやすさ（『親近性』）、街 の個性的な魅力（『個性』）の 3 つの分類を基に、対象とする街を位 置付け、各々の特性にとって適切な環境構成要素（照明の色・看板 など）とその特徴を選択していく、という方策が考えられる。

注記

注 1) 面接調查は東京大学工学部 1 号館にて行い、被験者には現場に直接行か せていない。

注 2）今回は繁華街などを主体とする都市公共空間の景観評価を主眼としてい ることもあり、安全性に関する項目は除外した。

注3）評価という用語の使用による誤解・混乱を避けるため、これ以降「6. ま とめ」を除き、構造化における表現である〈判断〉という表記を行う。総 合評価については、キャプション評価法（注 5 参照）を参考にし、公共空 間という場の総合評価としては客観性の強い「良い一悪い」という尺度が 妥当だと考え、当尺度を本研究における都市公共空間における総合評価の ための〈判断〉尺度として採用した

注 4）被験者には、視点場と視線方向を指示はしたが、そもそも被験者はその 場所へ移動する過程をも含めた周りの情報も考慮して評価していると考え られること、また本研究においては評価対象の特徵を把握することを主眼 とし評価対象の定量化は狙っていないことなどから、被駧者の目に入って くる景観要素に関しては、被験者間の捉え方の違いをある程度許容してい る

注 5) キャプション評価法は、本来写真撮影という行為をトリガー（評価の きっかけ）として景観評価を行い、意識に表出した評価を写真のキャプ ションという形の言語情報として抽出するものであり、評価者自体の認識 から、印象評価において重要な評価項目 (本研究における景観構成要素) を遵き出すことを目的とする。なお本研究においては写真撮影を被験者に は課さず、あらかじめ用意した写真を提示する方法を採ったが、被験者に 回答させる形式に関してキャプション評価法を参考にしている。

注 6）撮影に用いたカメラは Nikon F4、レンズは $28 \mathrm{~mm}$ であった。撮影者は 視点場に立ち、視線方向にカメラを向けて撮影した。なおスライド実験 (4.) ではこの写真を利用している。

注 7）紙面の関係上分析に用いなかった項目は表 8に記載していない。

注 8）被験者には、写真を撮らせることにより視点場と視線方向への意識付け を行うため、およびアンケート調査結果を実験者が写真によって確認する ために、評価対象空間を撮影させた。

注 9）本分析は、評価尺度 $\times 「$ 評価対象（被験者ごとに評価対象が異なる)」 の 2 元デー夕に対する因子分析であり、因子分析を行う際に、現場印象評 価実験 (2.)のように尺度ごとの評定平均値を求めてはいない。

注 10）個人差の影響から、各因子の奇与率が平滑化する可能性が考えられる が、その中でこの数值は充分に高いものと判断した。

注 11）各尺度の因子負荷量が、双方の因子分析において若干異なっており、 特に「開放的な」という尺度では差が顕著だが、因子構造を論ずるに当 たって、全体として上位 3 因子が同じであると見なすには問題のないレベ ルと判断した。

注 12）紙面の都合上、ここでは照明に関するものでかつ危険率 $1 \%$ で有意差 ありという結果となった景観構成要素のグラフのみを揭載する。

注 13）『秩序』因子のみが、総合評価との関連性が薄いことから、以下のまと めにおいては『秩序』因子、『親近性』因子、『個性』因子の順に並べて説 明をしていく。なお今回の結論は、都心部や人の集中する場である繁華 街、オフィス街、ショッピング街などの都市公共空間に限った結論として いる。

参考文献

1) 槙究、乾正雄、中村芳樹 : 評価項目が街路景観評価に及ぼす影響、日本建 築学会計画系論文集、第 468 号、pp.27-36、1995 年 2 月

2) 槙究、乾正雄、中村芳樹 : 街路景観評価の個人差について、日本建築学会 計画系論文集、第 483 号、pp.55-62、1996 年 5 月

3) 植究、乾正雄、中村芳樹 : 街路景観の評価構造の安定性、日本建築学会計 画系論文集、第 458 号、pp.27-33、1994 年 4 月

4) 望月菜穂子、阿部由香里、中村芳樹他 2 名 : ライトアップの印象に関する 研究、日本建築学会大会学術講演梗概集 (東北)、pp.81-84、1991 年9月

5) 山本公夫 : 都市公共空間における照明デザインの考え方と効果、照明学会 誌、第 74 巻、第 3 号、pp.137-142、1990年 3 月

6) 山本公夫 : 都市空間における照明環境の心理的評価、照明学会誌、第 78 巻、第 11 号、pp.595-598、1994年 11 月

7) 古賀誉章、高明彦他 4 名: キャプション評価法による市民参加型景観調查 一都市景観の認知と評価の構造に関する研究 その 1 一、日本建築学会計 画系論文集、第 517 号、pp.79-84、1999 年 3 月
8) 吉沢望、平手小太郎：都市空間における照明の認識 異なる属性間の認識 の差晎に関して、日本建築学会大会学術講演梗概集 (関東), pp.367-368、1997 年 9 月

9) 中村芳樹：都市景観照明の印象評価、照明学会誌、第 78 巻、第 11 号、 pp.143-148, 1994 年 11 月

（2001年 4 月 10 日原稿受理，2001年 8 月 3 日採用決定 